\title{
Interactions Between Soil Erosion Processes and Fires: Implications for the Dynamics of Fertility Islands
}

\author{
Sujith Ravi, ${ }^{1}$ Paolo D'Odorico, ${ }^{2}$ Travis E. Huxman, ${ }^{3}$ and Scott L. Collins ${ }^{4}$ \\ Authors are ${ }^{1}$ Postdoctoral Research Associate and ${ }^{3}$ Associate Professor, B2 Earthscience \& UA Biosphere 2, University of Arizona, Tucson, AZ 85721, \\ USA; ${ }^{2}$ Associate Professor, Department of Environmental Sciences, University of Virginia, Charlottesville, VA 22904, USA; and ${ }^{4}$ Professor, Department \\ of Biology, University of New Mexico, Albuquerque, NM 87131, USA.
}

\begin{abstract}
Shrub encroachment in arid and semiarid rangelands, a worldwide phenomenon, results in a heterogeneous landscape characterized by a mosaic of nutrient-depleted barren soil bordered by nutrient-enriched shrubby areas known as "fertile islands." Even though shrub encroachment is considered as a major contributor to rangeland degradation, little is known about mechanisms favoring the reversibility of the early stages of this process. Here we synthesize the interactions between fires and soil erosion processes, and the implications of these interactions for management of rangelands. The burning of shrub vegetation develops relatively high levels of soil hydrophobicity. This fire-induced water repellency was shown to enhance the soil erodibility in and around burned shrub patches. The fire-induced enhancement of local-scale soil erosion results from changes in the interparticle bonding forces between the soil grains, thus altering the way moisture is retained in the soil. It has been shown - with a number of wind-tunnel studies, field-scale manipulative experiments, microtopographic measurements, and isotopic tracer studies-how the fire-erosion interactions affect the dynamics of fertility islands. Further we propose a new conceptual model of resource "island" dynamics that explains some of the findings previously reported in the literature on the interactions between aeolian processes and arid-land vegetation. In particular, we highlight the ability of fires to enhance the erodibility of nutrient-rich soils accumulated under the shrubs favoring the redistribution of soil resources, thereby contributing to the reversibility of the early stages of shrub encroachment.
\end{abstract}

\section{Resumen}

La invasión de arbustos en pastizales áridos y semiáridos, un fenómeno mundial, genera un paisaje heterogéneo caracterizado por un mosaico de suelo estéril sin nutrientes, rodeado por un área de arbustivas enriquecida en nutrientes que se conocen como "islas de fertilidad". Aunque el aumento de los arbustos se considera como el mayor factor de la degradación de los pastizales, poco se sabe acerca de los mecanismos que favorecen el regreso a las etapas iniciales de este proceso. Aquí resumimos la interacción entre fuego y el proceso de erosión del suelo y las implicaciones de estas interacciones relacionadas al manejo de pastizales. La quema de la vegetación arbustiva genera relativamente altos niveles de hidrofobicidad en el suelo. Este fuego induce repelencia al agua y ha mostrado erosión del suelo cerca y alrededor de los espacios entre los arbustos. El fuego erosiona, a nivel local, dando como resultado cambios de las fuerzas de enlace entre partículas entre los granos de suelo y por tanto alterando la forma de retención de la humedad. Se ha demostrado con un número de estudios en túneles de viento, experimentos manipulados a nivel escala-campo, con quemas controladas, y mediciones micro topográficas; y estudios con trazadores de isotopos-cómo la interacción fuego-erosión afecta la dinámica de la invasión arbustiva. Además proponemos un nuevo modelo conceptual del recurso "isla” la dinámica que explica algunos de los resultados previamente reportados en la literatura sobre las interacciones entre procesos eólicos y vegetación de zonas áridas. En particular, subrayamos la habilidad del fuego para incrementar la erosión de los suelos ricos en nutrientes acumulados bajo los arbustos favoreciendo la redistribución de los recursos del suelo, por lo tanto contribuyendo al regreso de las etapas iniciales de la invasión de arbustivas.

Key Words: land degradation, resilience, shrub encroachment, thresholds

\section{INTRODUCTION}

Dry lands are of critical concern in that they cover about $40 \%$ of the earth's terrestrial surface-including semiarid, arid, and hyperarid regions-and support a human population of over 2

Research was funded by the National Science Foundation (grants EAR 0746228, DEB 0717360 DEB 0743678, and DEB 0620482 to the University of New Mexico for Long-Term Ecological Research) and the Philecology Foundation of Fort Worth, Texas, for UA Biosphere 2.

Correspondence: Sujith Ravi, B2 Earthscience, University of Arizona, 845 N Park Ave, Tucson, AZ 85721, USA. Email: ravi@email.arizona.edu

Manuscript received 2 May 2009; manuscript accepted 26 February 2010. billion, mostly in the developing world (Millennium Ecosystem Assesment [MEA] 2005). Rangelands (65\%) and croplands (25\%) account for almost $90 \%$ of all dry lands (MEA 2005). Land degradation in arid and semiarid rangelands is taking place at an alarming pace, leading to substantial reduction in ecosystem function and services (Dregne 2002; Reynolds et al. 2007) with subsequent environmental and socioeconomic implications. Climate change, overgrazing, lack of proper soil management practices, and shifts in vegetation composition (e.g., woody plant encroachment or invasion of exotic species) have rendered rangeland systems susceptible to degradation 


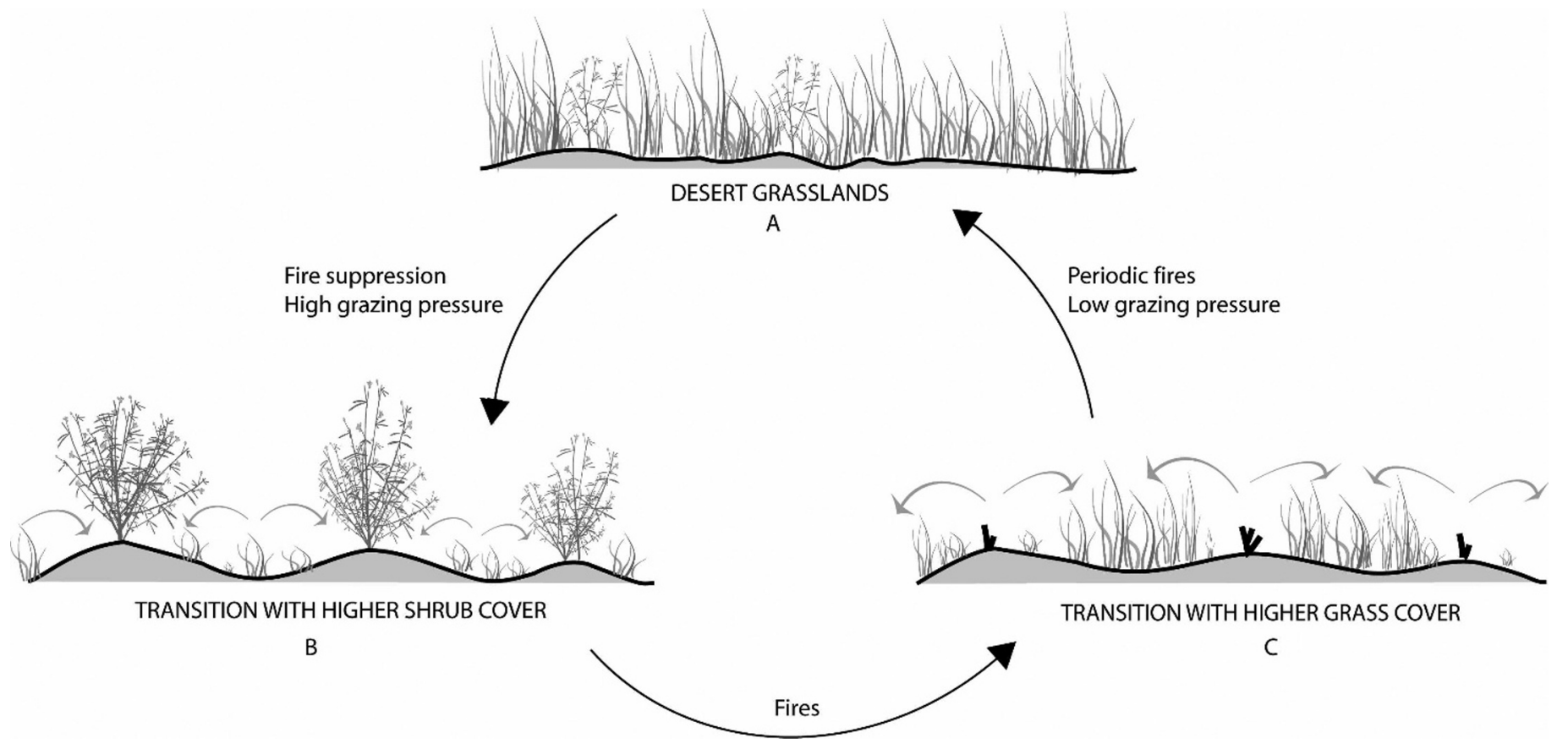

Figure 1. Schematic showing the interaction among vegetation, soil erosion, and fires in the shrub encroachment dynamics. A, uniform grassland with homogeneous distribution of resources; B, encroachment of shrubs into grassland and formation of islands of fertility; C, postfire redistribution of resources from the islands that favors enhanced grass regrowth in the interspaces. The postfire source-sink changes in shrub patches are indicated by the directional change of aeolian transport of sediments (gray arrows).

with important implications for global desertification and feedbacks to climate change (Schlesinger et al. 1990; D'Antonio and Vitousek 1992; Nicholson et al. 1998; Van Auken 2000; Ravi et al. 2009a). Hence understanding the biophysical processes contributing to rangeland degradation is motivated by the increasing need to estimate long-term changes in food and fodder supply, design and evaluate soil conservation and land-reclamation programs, assess the rate of entrainment of dust in the atmosphere and its contribution to global climate change, and analyze the effect of climate change and land management scenarios. Here we 1) review the dynamics of the shrub encroachment process in arid and semiarid rangelands, 2) synthesize the interactions between fires and soil erosion and their implications on the reversibility of the shrub-encroachment process in the early stages, and 3) propose a conceptual model for the postfire reversibility of shrub encroachment.

\section{SHRUB ENCROACHMENT AS A MANIFESTATION OF LAND DEGRADATION}

A common form of land degradation in rangelands involves a relatively rapid shift in plant community composition from grass to woody plant dominance, with the encroachment of woody plants into areas historically dominated by grasses (Archer 1989; Van Auken 2000). This phenomenon, commonly referred to as "shrub encroachment," has been well documented in many regions of the world (Buffington and Herbel 1965; Archer 1989; Van Auken 2000; Roques et al. 2001; Cabral et al. 2003; Fensham et al. 2005; Ravi et al. 2009b). Shrub encroachment into rangeland ecosystems impacts forage production (both quantity and quality) and interferes with livestock grazing and management practices (Scifres 1980). The encroachment of woody plants into productive rangelands can result from the complex interaction among several factors including changes in climate, increase in atmospheric $\mathrm{CO}_{2}$ levels, atmospheric deposition, and other anthropogenic disturbances (Schlesinger et al. 1990; Archer et al. 1995; Van Auken 2000).

Human activities have a profound influence on the processes contributing to rangeland degradation (Asner et al. 2004; Reynolds et al. 2007). The loss of productive rangelands as a result of anthropogenic disturbances and management practices has dramatically increased over the past century (UNCCD 1994; MEA 2005). The decline in fire size and frequency in grasslands (e.g., central and southwestern United States) is thought to be a critical factor responsible for the rapid expansion of shrubs (Humphrey 1958; McPherson 1995). Large-scale commercial grazing in conjunction with management practices such as fire suppression led to an increase in woody plants (shrub encroachment) with negative impacts on ecosystem function and services (Archer 1989; Van Auken 2000).

The shrub encroachment process results in the formation of a patchy landscape with nutrient-rich shrub patches referred to as "islands of fertility" or "resource islands," scattered among patches of grasses and nutrient-depleted bare soil interspaces (Schlesinger et al. 1990; Okin and Gillette 2001). The formation of islands of fertility is attributed to both abiotic and biotic processes such as local-scale variations in soil erosion and deposition (Fig. 1), plant uptake of water and nutrients by lateral roots spreading into the surrounding soils, nitrogen fixation by desert shrubs, and activities of soil microand macro-organisms (Garcia-Moya and McKell 1970; Char- 
ley and West 1975; Schlesinger et al. 1990). Thus the loss of resources from bare interspaces and the autogenic fertilization of shrub islands results in the replacement of relatively uniform grasslands by heterogeneous shrub-encroached landscapes (Fig. 1). This shift in plant community composition and in the spatial distribution of soil resources has important ecological, hydrological, and biogeochemical implications (Schlesinger et al. 1990; Huxman et al. 2005; Knapp et al. 2008). Further, shrub-encroached landscapes typically have more bare soil (e.g., Parsons et al. 1996; Schlesinger et al. 1999) and are prone to increased aeolian soil erosion (Huenneke et al. 2002; Ravi et al. 2007a; Breshears et al. 2009), which maintains and enhances the local heterogeneities in soil resources between the nutrient rich vegetated patches and the nutrient depleted bare interspaces (Schlesinger et al. 1990; Okin and Gillette 2001).

A few positive-feedback mechanisms have been invoked to explain the persistent and catastrophic nature of this land degradation process (Schlesinger et al. 1990; Anderies et al. 2002). For example, in the case of the southwestern United States, the introduction of cattle after European settlement led to an enhancement of mesquite seed dispersal, the degradation of the grass layer, and a reduction in fire frequency and intensity (Archer 1989; Van Auken 2000). These processes triggered a self-sustained cycle of erosion, depletion of soil resources, and vegetation loss in grass-dominated areas (Archer et al. 1995; Okin et al. 2009b), whereas the encroachment of shrubs was favored by the deposition of nutrient-rich sediments transported by wind and water, and the consequent formation of fertile shrub patches (Fig. 1), which was further sustained by the presence of shrub vegetation. At the same time, the loss in grass fuel decreased the frequency and intensity of fires, thereby further sustaining additional vegetation changes. Overall, this landscape-scale degradation is manifested as an increase in the spatial heterogeneity of soil resources, microtopography, and vegetation and by an increase in the extent of nutrient-depleted bare soil areas (Schlesinger et al. 1996; Okin et al. 2001). Despite the significance of shrub encroachment process, the factors controlling its reversibility remain poorly understood.

\section{IS SHRUB ENCROACHMENT A REVERSIBLE PROCESS?}

As stated above, land-management practices like fire suppression and overgrazing may lead to the dominance of woody plants. These processes result in grass mortality and subsequent loss of fuel load and grass connectivity, which further suppress or limit fires in the system. Moreover, as the grass cover decreases, wind and water erosion increase, eventually driving landscapes with sandy soils into a coppice dune-land state (Ravi et al. 2007a).

Until recently the process of fertility island formation associated with grassland-to-shrubland conversion was thought to be highly irreversible, at least after encroachment crosses some threshold (Peters et al. 2006). However, our studies have shown that there exists a very dynamic state of shrub-grass transition, in which fire may play a major role in determining the recovery of grasses. In particular, the interaction between fires and aeolian processes is thought to have a possible negative feedback on the encroachment of shrubs into desert grasslands (Ravi et al. 2009b). The postfire enhancement of resource redistribution from the fertile shrub islands to bare interspaces counteracts the heterogeneity-forming processes contributing to the emergence of fertility islands and the encroachment of shrub vegetation (Fig. 1). Hence the fertility islands are not necessarily static features of rangeland ecosystems; rather they can be highly dynamic (Fig. 1). This synthesis is particularly concerned with the fertility island dynamics resulting from the interaction between wind erosion and fire and with the effect of fire-soil erosion feedbacks on the spatial patterns of vegetation and soil resources in shrubencroached arid rangelands.

\section{FIRE-EROSION FEEDBACKS IN SHRUB ENCROACHED RANGELANDS}

The increase in woody plants in rangelands-induced by either anthropogenic or environmental factors-leads to a decline in grass cover and to a presumed shift to an alternative (stable) state of shrubland (Scheffer and Carpenter 2003). However, many systems exist in the transition state between grassland and shrubland. The major ecosystem properties in these shrubgrass transition systems are determined by the heterogeneity of resources and the connectivity of grass cover between the vegetated patches (Okin et al. 2009a; Ravi et al. 2009a). The local heterogeneities in nutrient and vegetation distribution in arid rangelands are maintained and enhanced by local soilerosion processes. In fact, aeolian erosion, which dominates in these arid rangelands (Breshears et al. 2009), is responsible for the removal of nutrient-rich soil from intercanopy areas and subsequent deposition onto vegetated patches (Schlesinger et al. 1990; Okin et al. 2001). Periodic fires also affect the dynamics of these transition systems. In many shrub-encroached grasslands there exists enough grass cover to provide connectivity for fire spread. Fires, on the other hand, are known to affect the abundance and distribution of shrubs and grasses in arid ecosystems (Anderies et al. 2002; Sankaran et al. 2004; D'Odorico et al. 2006; Parmenter 2008). Vegetation, in turn, affects the frequency, season, and behavior of fires (McPhearson 1995; van Wilgen et al. 2003). Although both soil erosion and fires affect the dynamics of semiarid rangelands, only a few studies have addressed the interaction between these two processes.

In desert grasslands and shrublands the erodibility of soils in burned areas has been found to be several orders of magnitude larger than that of adjacent unburned or cleared areas (Whicker et al. 2002; Ravi et al. 2007b; Sankey et al. 2009). Thus, as a result of fires the export of dust and contaminants to the atmosphere increases. Until recently, the mechanisms responsible for the postfire enhancement of the rates of aeolian erosion were not fully understood. Our studies on grasslands and shrub-encroached areas in the southwestern United States have shown that fires increase wind erosion rates in burned areas and the increase is considerably stronger for shrubencroached grasslands compared to landscapes covered only by grasses (Ravi et al. 2007b). Wind-tunnel studies using soils collected from burned shrub-grass transition zones showed that the erodibility of soils from burned shrub patches increased 
considerably after fire, whereas this postfire enhancement in soil erosion rates was negligible under grasses and bare interspaces (Figs. 2A and 2B). This enhancement in erosion rates has been attributed to postfire soil water repellency (or hydrophobicity) induced by the burning of plant biomass (Ravi et al. 2006a). This explanation is supported by the following two observations: 1) no enhancement in erosion rates was observed in adjacent unburned areas with similar surface roughness and experiencing similar wind shear (Ravi et al. 2009b); 2) wind-tunnel studies on clean sand not exposed to any burn, but treated with water-repellent organic compounds typically released by burning plant biomass showed an enhancement of soil erodibility with respect to the untreated soils (Ravi et al. 2006a). Further, a mechanistic framework can explain this effect as the result of the weakening of the interparticle bonding forces due to the interaction of soil moisture with water repellent soil grains (Ravi et al. 2006a, 2009c).

Burning vegetation releases different organic compounds that induce different levels of water repellency in the soil, depending on several factors such as vegetation type, soil properties, moisture availability, fire intensity, and duration (DeBano 2000; Doerr et al. 2000). Shrubs typically release more hydrophobic organics and burn at higher temperatures compared to grasses, thus explaining the more severe postfire water repellency found in and around shrub patches. These effects of fires on soil properties (e.g., water repellency and reduced soil infiltration capacity) were observed only at the soil surface (top few centimeters), where soil properties affect erosion rates. Thus our wind-tunnel studies and field experiments demonstrated that the typical rangeland fires are able to induce soil water repellency and enhance wind erosion rates in soil patches affected by the burning of shrub vegetation (Ravi et al. 2007b, 2009b).

This fire-induced water repellency is also known to decrease infiltration and enhance water erosion and runoff (at local scale) with subsequent ecological and hydrogeomorphic consequences (Doerr et al. 2000; MacDonald and Huffman 2004). Further, soil hydrophobicity affects the adsorption and retention of moisture in the soil (Ravi et al. 2006a), making the surface soil more susceptible to erosion by wind and water (Doerr et al. 2000; Ravi et al. 2007b). By limiting the adsorption of moisture on soil grain surface and decreasing the strength of interparticle wet bonding forces between soil grains, fire-induced soil water repellency enhances soil erodibility by wind. To our knowledge, until recently the role of soil water repellency in wind-erosion processes taking place in arid and semiarid rangelands has remained poorly understood.

Wind erosion occurs when the wind speed exceeds a critical threshold value that depends on the erodibility of the soil surface. The resulting dust flux is a function of this threshold velocity, which, in turn, depends both on factors affecting the action of wind on the soil surface (e.g., surface roughness, vegetation cover), and on factors determining the interparticle bonding forces between soil grains. In particular, the threshold velocity for erosion is found to decrease (with an associated increase in soil erodibility) with increasing values of the interparticle bonding forces (Shao and Lu 2000; Ravi et al. 2004, 2006b). Ravi et al. (2006a) developed a theoretical
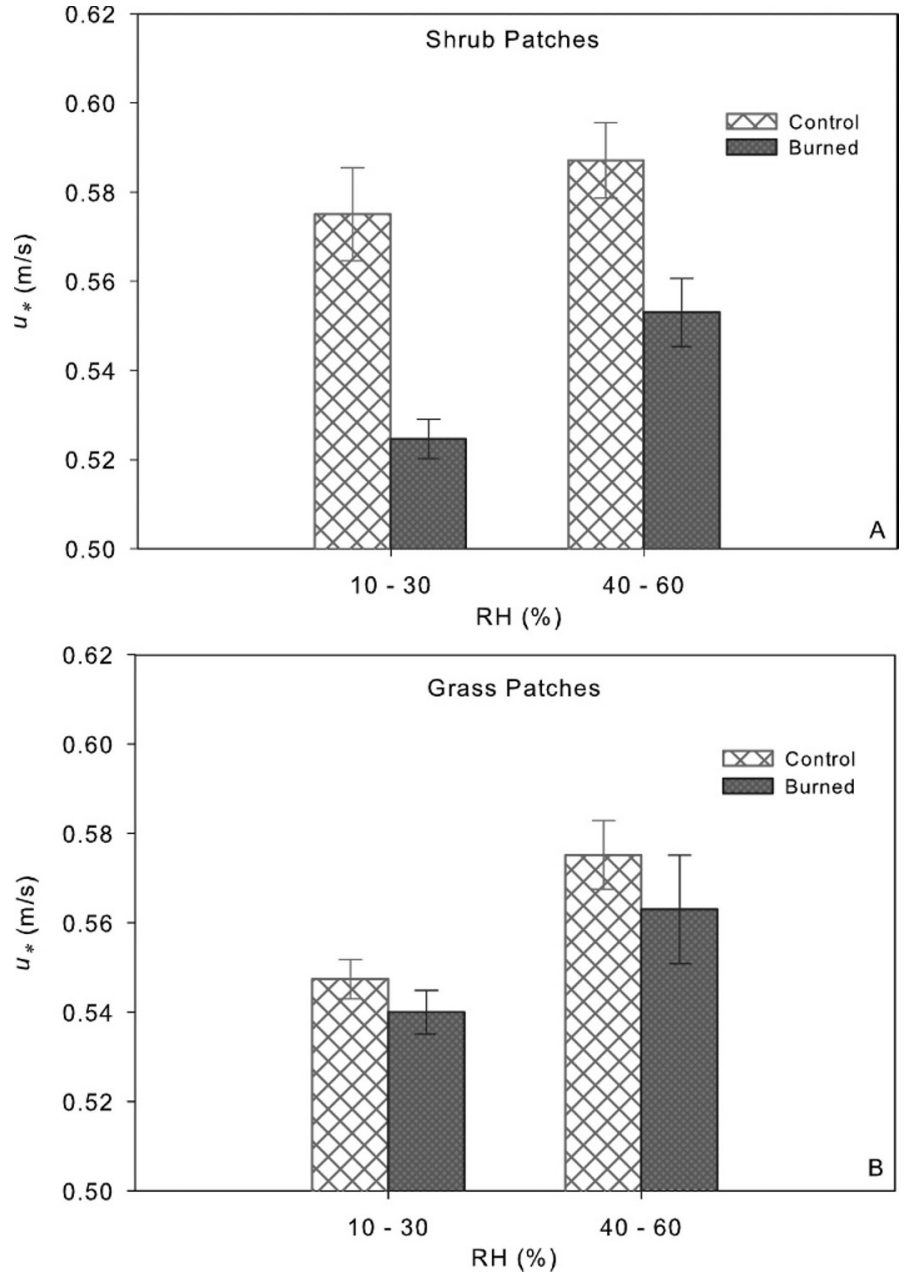

Figure 2. Threshold shear velocity $\left(u_{\star}\right)$ for aeolian erosion (minimum wind velocity needed for erosion to happen) determined with the use of wind-tunnel tests for control and burned soils from $\mathbf{A}$, shrub patches and B, grass patches at Sevilleta National Wildlife Refuge, New Mexico. The experiments are repeated at two ranges of air humidity $(\mathrm{RH})$ to account for the effect of air humidity on surface soil moisture (and on $u_{\star}$ ) for air dry soils. The erodibility of soils in the unburned areas was unaffected by the burn (data from Ravi et al. 2007b).

model to explain the dependence of interparticle forces on soil water repellency and showed that the interparticle forces decrease (hence, soil erodibility increases) with the increase in soil water repellency (as quantified by an increase in soil-water contact angle). Thus, the enhancement of aeolian transport in soil affected by fire may be explained by the fact that hydrophobic compounds (released by the burning of mostly woody biomass) affect interparticle bonding between soil grains. These results are consistent with other field (Whicker et al. 2002; Ravi et al. 2009b; Sankey et al. 2009) and windtunnel (Ravi et al. 2007b) studies on the effect of fires on aeolian transport processes in arid and semiarid regions.

\section{POSTFIRE FERTILITY ISLAND DYNAMICS}

It is still unclear how the interactions between soil erosion and fires affect the dynamics of fertility islands and vegetation in 
shrub-encroached grasslands. As described above, soil processes interact with disturbances such as fires to modify the rates of soil erosion and resource redistribution in these systems. In a heterogeneous landscape with shrubs, grasses, and bare interspaces, the burned shrub patches exhibited higher soil erosion rates compared to burned grass patches and bare interspaces (Ravi et al. 2007b). The local scale increase in soil erodibility contributes to the resource homogenization in the system with implications for resulting vegetation patterns. Our field experiments with microtopography bridges and ${ }^{15} \mathrm{~N}$ isotopic tracers proved that there were larger translocation rates of sediments and nutrients (especially nitrogen) from the burned shrub islands to the interspaces compared to vegetation denuded islands, even when both are experiencing same erosive action of wind and water (Ravi et al. 2009b). These field experiments were conducted in grassland in the northern Chihuahuan desert (Sevilleta National Wildlife Refuge [NWR], New Mexico) exhibiting shrub encroachment with welldeveloped fertile shrub islands (Kieft et al. 1998; Baez and Collins 2008). In this system the grass understory was still present and provided sufficient connectivity for fires to spread. The isotopic tracer studies conclusively proved that the grasses growing in the interspaces of burned areas received significantly greater amounts of nutrients compared to those in denuded areas not affected by fires (Ravi et al. 2009b). The postfire breakdown of resource (or fertility) islands and subsequent homogenization of resources favors enhanced grass growth. The enhanced grass cover increases the chances of fires in the system, which further drives the system towards a grassdominated state. Thus soil erosion, which maintained and enhanced heterogeneity, can also lead to postfire resource homogenization. The postfire modifications in sediment source/ sink patches, in turn, affect soil biogeochemical processes and vegetation patterns, with the general effect of reducing the heterogeneity in soil resource distribution and enhancing grass regrowth (Fig. 1). Thus, the islands of fertility formed by shrubs in fire-affected rangeland systems are thought to be dynamic features of the landscape. However, the long-term response of fertility-island dynamics to the reintroduction of fires after decades of fire control or suppression still needs to be investigated.

Ravi and D'Odorico (2009) developed a spatially explicit state-and-transition model to demonstrate the dynamic nature of fertility islands and the reversibility of the process of shrub encroachment. This modeling study investigated the relative role of fire and grazing in shrub-encroached rangeland systems and showed that in shrub-grass transition zones, fires, if applied at the early stages of encroachment, have the ability to prevent the progression of the system toward a stable shrubland state (Figs. 3A and 3B). The model simulation without postfire enhancement of erosion from burned shrub patches indicates that in the absence of this process, grass recovery is slower and partial. This study provided also a process-based qualitative framework to show how the homogenization of the landscape may, in turn, favor the re-establishment of grass cover in the interspaces (Fig. 3B). A more continuous grass cover, in turn, would enhance the size and frequency of fires, which are a major disturbance for shrubs (e.g., D’Antonio and Vitousek 1992). Thus, the feedbacks between fires and soil erosion (with enhancement of postfire resource redistribution) contribute to
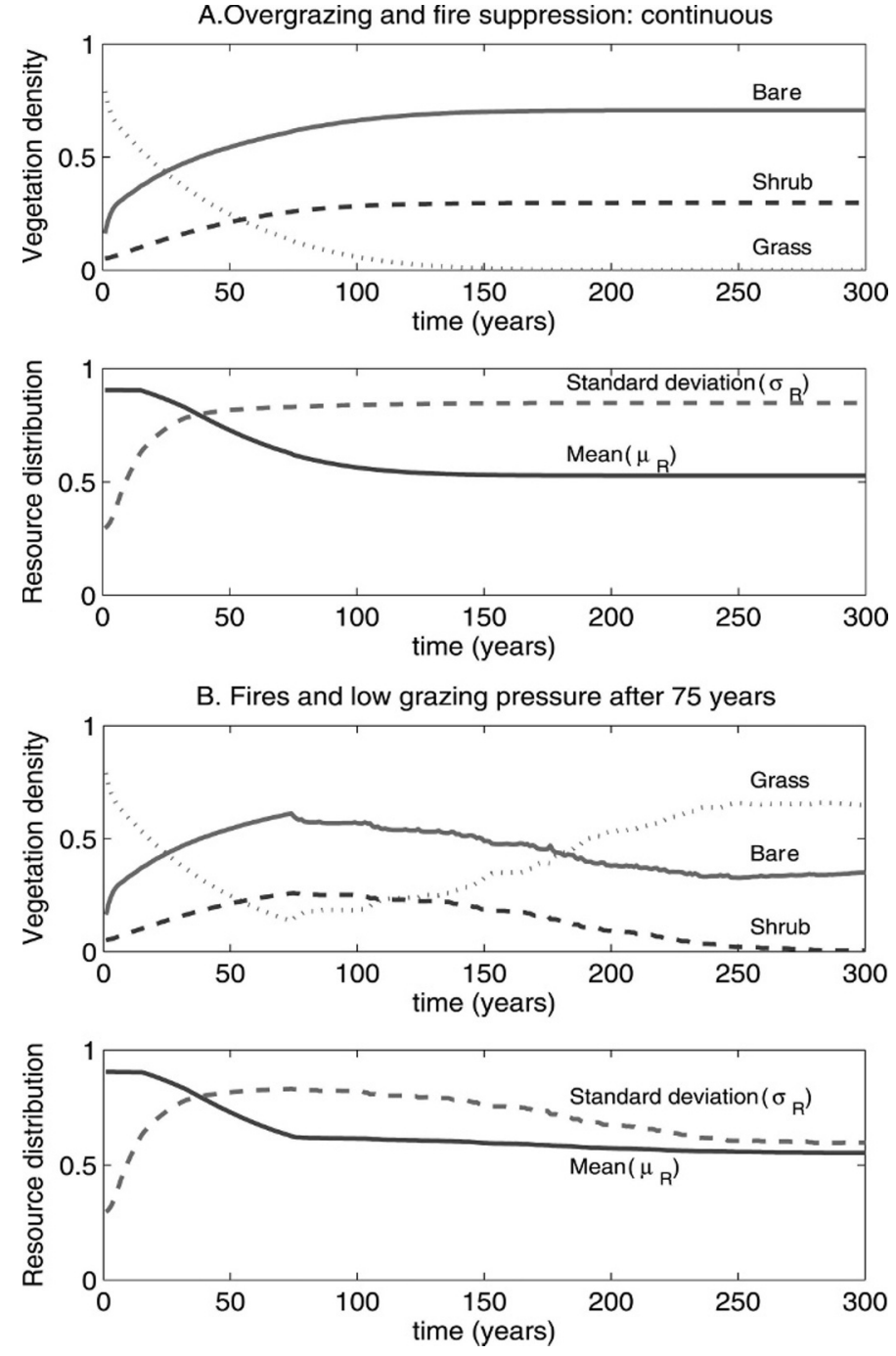

Figure 3. Simulation of vegetation and resource distribution with different land use scenarios: A, continuous overgrazing and fire suppression; and B, same as earlier for the first $75 \mathrm{yr}$; after that grazing pressure was decreased and fires were not suppressed (modified from Ravi and D'Odorico 2009).

the reversibility of vegetation dynamics in these landscapes, and to the dynamics of the islands of fertility.

We acknowledge that there are several confounding factors that affect our conclusions. The results of the experiments discussed above may be affected by the particular rangeland system investigated-the Chihuahuan desert grasslands (Sevilleta, NWR, New Mexico). Similar studies are required in other rangeland systems to investigate the applicability of these results. The proposed mechanism for the reversibility of shrub encroachment is applicable to systems where fires are still active. This means that there needs to be sufficient connectivity between the shrub islands for fires to spread (Fig. 4). The results also depend on the species and growth stage of the encroaching shrubs, as these factors affect the mortality by fires and resprouting (McLaughlin and Bowers 1982; Trollope 1996). For example, when the encroached shrubs are relatively young, fires can result in high shrub mortality. However, in the case of mature shrubs, the fire mortality is significantly 


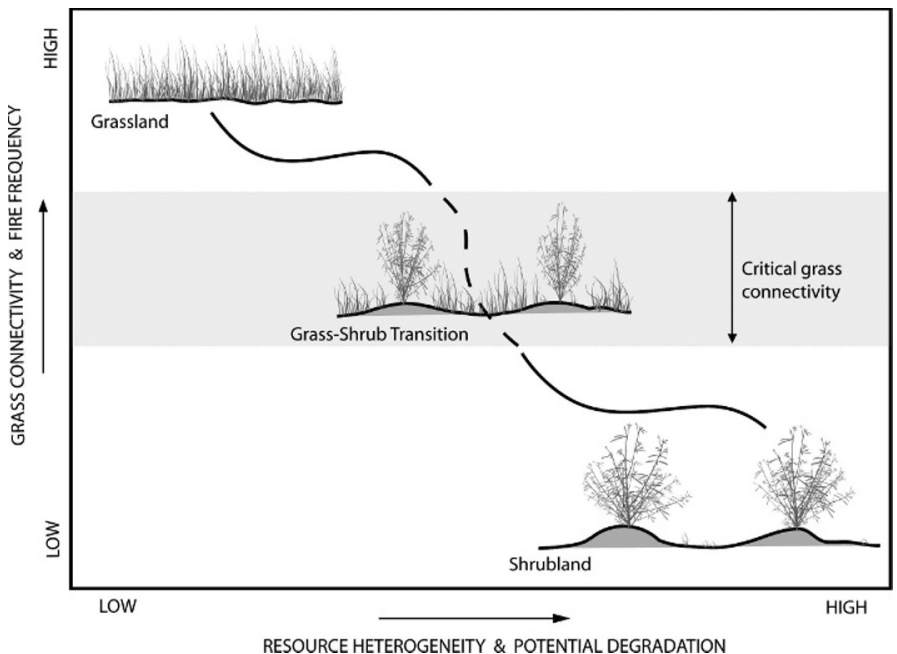

Figure 4. Schematic showing the region of critical grass connectivity where fire may play a key role in the reversibility of the grassland-toshrubland transition.

reduced. Fire frequency, intensity, and season are also important, as fires applied at the peak of the windy season or during extended periods of drought can lead to greater losses of resources from the system, as a result of exposure of the soil surface to the erosive action of wind. Fires can affect the structure and stability of microbial crusts, with implications for the soil redistribution processes. However, in the system investigated, the microbial crusts were observed only in the bare interspaces and not directly under the shrub patches, consistently with the findings from other arid rangeland systems (Schlesinger and Pilmanis 1998).

The process of shrub encroachment is often investigated in the context of "state and transition theories" (Bestelmeyer et al. 2003; Briske et al. 2008), whereby the grassland and shrubland land covers are viewed as alternative stable states in a bistable system (Westoby et al. 1989). In this framework, the replacement of the grassland by shrub vegetation is interpreted as a regime shift to the other stable state because of changes in environmental conditions or disturbance regime. Because the shrubland is also stable, the re-establishment of the initial environmental/disturbance conditions does not necessarily lead to the recovery of the grassland state. Thus, the underlying bistable dynamics are characterized by the presence of critical thresholds, are prone to highly irreversible transitions, and their states may have only a limited resilience. Our study shows that these transitions can be less abrupt and irreversible than commonly thought: Before shifting to a state dominated by shrubs and bare soil, the system may exhibit a mixture of shrubs with grass understory that can be reversed back to the grassland state using fire as a management tool. In fact, the interaction of fire with wind erosion can favor the reestablishment of a grass cover by restoring a more homogeneous distribution of soil resources (Ravi et al. 2009b). This research has potential implications for the sustainability of agricultural and rangeland systems in arid and semiarid regions and the response of these systems to management practices and global climate change scenarios.

\section{MANAGEMENT IMPLICATIONS}

The experimental findings discussed in the above sections indicate that the postfire resource homogenization in shrubencroached rangelands is a rapid process occurring in the time frame of weeks. Moreover, field observations have indicated that the water repellency induced by fires is short lived (i.e., of the order of a few weeks) in these rangelands. Hence, by altering soil surface physical and chemical properties for a short period, fires can counteract the heterogeneity-forming dynamics of land degradation associated with shrub encroachment. Because of this effect of fires, islands of fertility can be dynamic rather than static features of these landscapes. This synthesis discusses the possibility that fire can mitigate the early stages of land degradation associated with grassland-to-shrubland conversions. In particular, we show that at the early stages of woody plant encroachment in desert grasslands, fires play a major role in the local scale redistribution of soil resources, thereby counteracting the heterogeneity-forming dynamics of land degradation associated with woody plant encroachment. This redistribution is attributed to the enhancement of localscale soil-erosion processes, mainly aeolian, which dominate in these arid rangelands. These findings highlight the role of fire as a management tool in the early stages of the land-degradation process associated with woody plant encroachment in arid grasslands.

Rangeland management practices like grazing and fire management can impact the recovery of grasses. High grazing rates can weaken the grass cover and also facilitate enhanced shrub seed dispersal in these rangelands. If prescribed fires are followed by a period of low precipitation or drought, the grass regrowth may be inhibited. In this situation a potential loss of nutrients offsite may occur during the process of postfire resource redistribution. Similarly, grazing intensity should be managed to ensure grass recovery following the fires. Studies have indicated that removal of livestock grazing even for decades may not lead to the recovery of grasses in rangelands (Valone et al. 2002; Parmenter et al. 2008). A combination of controlled grazing and fires may be necessary to ensure the speedy recovery of grasses, because without periodic fires, the shrubs in the system would not be noticeably affected, as no mechanisms would be in place to contribute to shrub removal (Ravi and D'Odorico 2009). The major source of plant materials contributing to postfire grassland recovery is the remnant belowground grass biomass, though some regeneration can occur also from seeds. In many arid and semiarid rangelands experiencing shrub encroachment there exists sufficient grass biomass to provide sufficient sources (seed banks and belowground biomass) for the postfire grass recovery. Studies have shown that grass recovery may take several decades following fire (Parmenter et al. 2008), even though rapid recovery can occur depending on the postfire moisture availability (rainfall) and season of burning. In a system prone to invasions of annual rather than native perennial grasses, the postfire resource redistribution could lead to the dominance of invasive (annual) grasses. It has been argued that these grass invasions may replace drought tolerant shrub vegetation with a drought-prone cover of exotic grasses, leading in the long run to an unvegetated (desertified) 
landscape prone to erosion and loss of soil resources (Okin et al. 2009a; Ravi et al. 2009a).

\section{LITERATURE CITED}

Anderies, J. M., M. A. Janssen, and B. H. Walker. 2002. Grazing management, resilience, and the dynamics of a fire-driven rangeland system. Ecosystems 5:23-44.

ARCHER, S. 1989. Have southern Texas savannas been converted to woodlands in recent history. American Naturalist 134:545-561.

Archer, S., D. S. Schimel, and E. A. Holland. 1995. Mechanisms of shrubland expansion-land-use, climate or $\mathrm{CO}_{2}$. Climatic Change 29:91-99.

Asner, G. P., A. J. Elmore, L. P. Olander, R. E. Martin, and A. T. Harris. 2004. Grazing systems, ecosystem responses, and global change. Annual Review of Environment and Resources 29:261-299.

Baez, S., and S. L. Collins. 2008. Shrub invasion decreases diversity and alters community stability in northern Chihuahuan desert plant communities. PLOS ONE 3(6): 2332 .

Bestelmeyer, B. T., J. R. Brown, K. M. Havstad, R. Alexander, G. Chavez, and J. E. HerRick. 2003. Development and use of state-and-transition models for rangelands. Journal of Range Management 56:114-126.

Breshears, D. D., J. J. Whicker, C. B. Zou, J. P. Field, and C. D. Allen. 2009. A conceptual framework for dryland aeolian sediment transport along the grass land-forest continuum: effects of woody plant canopy cover and disturbance. Geomorphology 10591-2:28-38.

Briske, D. D., B. T. Bestelmeyer, T. K. Stringham, and P. L. Shaver. 2008. Recommendations for development of resilience-based state-and-transition models. Rangeland Ecology and Management 61:359-367.

Buffington, L. C., AND C. H. Herbel. 1965. Vegetational changes on a semidesert grassland range from 1858 to 1963. Ecological Monographs 35:139-164.

Cabral, A. C., J. M. De Miguel, A. J. Rescia, M. F. Schmitz, and F. D. Pineda. 2003. Shrub encroachment in Argentinean savannas. Journal of Vegetation Science 14:145-152.

Charley, J. L., and N. E. West. 1975. Plant-induced soil chemical patterns in some shrub-dominated semi-desert ecosystems of Utah. Journal of Ecology 63:945-963.

D’Antonio, C. M., And P. M. Vitousek. 1992. Biological invasions by exotic grasses, the grass fire cycle and global change. Annual Review of Ecology and Systematics 23:63-87.

D'Odorico, P., F. LaIO, AND L. Ridolfi. 2006. A probabilistic analysis of fire-induced tree-grass coexistence in savannas. American Naturalist 167:E79-E87.

Debano, L. F. 2000. The role of fire and soil heating on water repellency in wildland environments: a review. Journal of Hydrology 231:195-206.

Doerr, S. H., R. A. Shakesby, and R. P. D. Walsh. 2000. Soil water repellency: its causes, characteristics and hydro-geomorphological significance. EarthScience Reviews 51:33-65.

Dregne, H. E. 2002. Land degradation in the drylands. Arid Land Research and Management 16:99-132.

Fensham, R. J., R. J. Fairfax, and S. R. Archer. 2005. Rainfall, land use and woody vegetation cover change in semi-arid Australian savanna. Journal of Ecology 93:596-606.

Garcia-Moya, E., and C. M. McKell. 1970. Contribution of shrubs to the nitrogen economy of a desert-wash plant community. Ecology 51:81.

Huenneke, L. F., J. P. Anderson, M. Remmenga, and W. H. Schlesinger. 2002. Desertification alters patterns of aboveground net primary production in Chihuahuan ecosystems. Global Change Biology 8:247-264.

Humphrey, H. H. 1958. The desert grassland. Botanical Review 24:193-253.

Huxman, T. E., B. P. Wilcox, D. D. Breshears, R. L. Scott, K. A. Snyder, E. E. Small, K. Hultine, W. T. Pockman, and R. B. Jackson. 2005. Ecohydrological implications of woody plant encroachment. Ecology 86:308-319.

Kieft, T. L., C. S. White, S. R. Loftin, R. Aguilar, J. A. Craig, and D. A. Skaar. 1998. Temporal dynamics in soil carbon and nitrogen resources at a grasslandshrubland ecotone. Ecology 79(2):671-683.
Knapp, A. K., J. M. Briggs, S. L. Collins, S. R. Archer, M. S. Bret-Harte, B. E. Ewers, D. P. Peters, D. R. Young, G. R. Shaver, E. Pendall, and M. B. Cleary. 2008. Shrub encroachment in North American grasslands: shifts in growth form dominance rapidly alters control of ecosystem carbon inputs. Global Change Biology 14:615-623.

MacDonald, L. H., and E. L. Huffman. 2004. Post-fire soil water repellency: persistence and soil moisture thresholds. Soil Science Society of America Journal 68:1729-1734.

McLaughuin, S. P., and J. E. Bowers. 1982. Effects of wildfire on a Sonoran desert plant community. Ecology 63(1):246-248.

McPherson, G. R. 1995. The role of fire in the desert grasslands. In: M. P. McClaran and T. R. van Devender [EDS.]. The desert grassland. Tucson, AZ, USA: The University of Arizona Press. p. 130-151.

[MEA] Millennium Ecosystem Assessment. 2005. Millennium Ecosystem Assessment: ecosystems and human well-being: desertification synthesis. Washington, DC, USA: World Resource Institute. 26 p.

Nicholson, S. E., C. J. Tucker, and M. B. BA. 1998. Desertification, drought, and surface vegetation: an example from the West African Sahel. Bulletin of the American Meteorological Society 79:815-829.

OKIN, G. S., P. D'Odorico, and S. Archer. 2009b. Impact of feedbacks on the stability of Chihuahuan desert grasslands. Journal of Geophysical Research 114:G01004. doi:10.1029/2008JG000833.

OKIN, G. S., AND D. A. GILletTe. 2001. Distribution of vegetation in wind-dominated landscapes: implications for wind erosion modeling and landscape processes. Journal of Geophysical Research-Atmospheres 106:9673-9683.

Okin, G. S., B. Murray, and W. H. Schlesinger. 2001. Degradation of sandy arid shrubland environments: observations, process modelling, and management implications. Journal of Arid Environments 47:123-144.

Okin, G. S., A. J. Parsons, J. Wainwright, J. E. Herrick, B. T. Bestelmeyer, D. C. Peters, and E. L. Fredrickson. 2009a. Do changes in connectivity explain desertification? Bioscience 59:237-244.

Parmenter, R. 2008. Long-term effects of a summer fire on desert grassland plant demographics in New Mexico. Rangeland Ecology and Management61:156-168.

Parsons, A. J., A. D. Abrahams, and J. Wainwright. 1996. Responses of interrill runoff and erosion rates to vegetation change in southern Arizona. Geomorphology 14:311-317.

Peters, D. P. C., B. T. Bestelmeyer, J. E. Herrick, E. L. Fredrickson, H. C. Monger, and K. M. Havstad. 2006. Disentangling complex landscapes: new insights into arid and semiarid system dynamics. Bioscience 56:491-501.

Ravi, S., and P. D'Odorico. 2009. Post-fire resource redistribution and fertility island dynamics in shrub-encroached desert grasslands: a modeling approach. Landscape Ecology 23(3):325-335.

Ravi, S., P. D’Odorico, S. L. Collins, and T. E. Huxman. 2009a. Can biological invasions induce desertification? New Phytologist 181:512-515.

Ravi, S., P. D'Odorico, B. Herbert, T. Zobeck, and T. M. Over. 2006a. Enhancement of wind erosion by fire-induced water repellency. Water Resources Research 42:W11422. doi:10.1029/2006WR004895.

Ravi, S., P. D'Odorico, and G. S. Okin. 2007a. Hydrologic and aeolian controls on vegetation patterns in arid landscapes. Geophysical Research Letters 34:L24S23. doi:10.1029/2007GL031023.

Ravi, S., P. D'Odorico, T. M. Over, and T. M. Zobeck. 2004. On the effect of air humidity on soil susceptibility to wind erosion: the case of air-dry soils. Geophysical Research Letters 31:Lo9501. doi: 10.1029/2004GL019485.

Ravi, S., P. D'Odorico, L. X. Wang, C. S. White, G. S. Okin, S. A. Macko, and S. L. Coluins. 2009b. Post-fire resource redistribution in desert grasslands: a possible negative feedback on land degradation. Ecosystems 12:434-444.

Ravi, S., P. D'Odorico, T. M. Zobeck, and T. M. Over. 2009c. The effect of fire-induced soil hydrophobicity on wind erosion in a semiarid grassland: experimental observations and theoretical framework. Geomorphology 105(1-2):80-86.

Ravi, S., P. D'Odorico, T. M. Zobeck, T. M. Over, and S. L. Coluins. 2007b. Feedbacks between fires and wind erosion in heterogeneous arid lands. Journal of Geophysical Research—Biogeosciences 112:G04007. doi:10.1029/2007JG000474.

Ravi, S., T. M. Zobeck, T. M. Over, G. S. Okin, and P. D'Odorico. 2006b. On the effect of moisture bonding forces in air-dry soils on threshold friction velocity of wind erosion. Sedimentology 53:597-609. 
Reynolds, J. F., D. M. S. Smith, E. F. Lambin, B. L. Turner II, M. Mortimore, S. P. J. Batterbury, T. E. Downing, H. Dowlatabadi, R. J. Fernandez, J. E. Herrick, E. Huber-Sannwald, H. Jiang, R. Leemans, T. Lynam, F. T. Maestre, M. Ayarza, and B. WALKER. 2007. Global desertification: building a science for dryland development. Science 316:847-851.

Roques, K. G., T. G. O'Connor, and A. R. Watkinson. 2001. Dynamics of shrub encroachment in an African savanna: relative influences of fire, herbivory, rainfall and density dependence. Journal of Applied Ecology 38:268-280.

Sankaran, M., J. Ratnam, and N. P. Hanan. 2004. Tree-grass coexistence in savannas revisited-insights from an examination of assumptions and mechanisms invoked in existing models. Ecology Letters 7:480-490.

Sankey, J. B., M. J. Germino, and N. F. Glenn. 2009. Aeolian sediment transport following wildfire in sagebrush steppe. Journal of Arid Environments 73:912-919.

Schefrer, M., and S. R. Carpenter. 2003. Catastrophic regime shifts in ecosystems: linking theory to observation. Trends in Ecology \& Evolution 18:648-656.

Schlesinger, W. H., A. D. Abrahams, A. J. Parsons, and J. Wainwright. 1999. Nutrient losses in runoff from grassland and shrubland habitats in Southern New Mexico: I. Rainfall simulation experiments. Biogeochemistry 45:21-34.

Schlesinger, W. H., and A. M. Pilmanis. 1998. Plant-soil interactions in deserts. Biogeochemistry 42:169-187.

Schlesinger, W. H., J. A. Raikes, A. E. Hartley, and A. F. Cross. 1996. On the spatial pattern of soil nutrients in desert ecosystems. Ecology 77(2):364-374.

Schlesinger, W. H., J. F. Reynolds, G. L. Cunningham, L. F. Huenneke, W. M. Jarrell, R. A. Virginia, AND W. G. Whitford. 1990. Biological feedbacks in global desertification. Science 247:1043-1048.
ScIFres, C. J. 1980. Brush management. Principles and practices for Texas and the southwest. College Station, TX, USA: Texas A\&M University Press. 360 p.

ShaO, Y. P., AND H. Lu. 2000. A simple expression for wind erosion threshold friction velocity. Journal of Geophysical Research-Atmospheres 105:2243722443.

Trollope, W. S. W. 1996. Behaviour, effects and use of fire in the savannas of southern Africa. In: T. C. Grice and S. M. Slatter [EDS.]. Fire in the management of northern Australian pastoral lands. Proceedings of the Tropical Grassland Society of Australia 8:9-23.

Valone, T. J., M. Meyer, J. H. Brown, and R. M. Chews. 2002. Timescale of perennial grass recovery in desertified arid grasslands following livestock removal. Conservation Biology 16(4):995-1002.

Van Auken, 0. W. 2000. Shrub invasions of North American semiarid grasslands. Annual Review of Ecology and Systematics 31:197-215.

Van Wilgen, B. W., W. S. W. Trollope, H. C. Biggs, A. L. F. Potgieter, and B. H. Brockett. 2003. Fire as a driver of ecosystem variability. In: J. T. Du Toit, K. H. Rogers, and H. C. Biggs [EDS.]. The Kruger experience: ecology and management of savanna heterogeneity. Washington, DC, USA: Island Press. p. 149-170.

Westoby, M., B. Walker, AND I. Noy-Meir. 1989. Range management on the basis of a model that does not seek to establish equilibrium. Journal of Arid Environments 17:235-239.

Whicker, J. J., D. D. Breshears, P. T. Wasiolek, T. B. Kirchner, R. A. Tavani, D. A. Schoep, and J. C. Rodgers. 2002. Temporal and spatial variation of episodic wind erosion in unburned and burned semiarid shrubland. Journal of Environmental Quality 31:599-612. 